\title{
Utilização do teste de paternidade como prova judicial no tribunal de justiça do sul de minas gerais
}

\author{
The paternity test utilization as a judicial proof in the court of southern minas gerais
}

\author{
Milena Moura Araújo Biazuzo ${ }^{1}$ \\ Erasmo Aparecido Piccolo ${ }^{2}$ \\ Allyne Pongo Menezes ${ }^{3}$
}

\begin{abstract}
RESUMO
Este artigo retrata a realização de testes de paternidade através do uso de DNA, os quais começaram a ser divulgados na mídia brasileira no final do século XX, por meio de programas populares de televisão e promoveu sua utilização em diversas camadas sociais do Brasil. A pesquisa retratou que o exame já era estudado no meio científico desde meados do século passado. O objetivo deste trabalho foi investigar quais os tipos de testes de DNA são realizados e se há eficácia probatória para o Tribunal de Justiça do Sul de Minas Gerais. Para tal constructo a pesquisa tomou perfil exploratório, descritivo, por meio de um roteiro de pesquisa, investigando, descrevendo e analisando os dados e abordagens dos chefes de cartório em $30 \%$ das varas cíveis do sul de Minas Gerais. Ao final, a pesquisa constatou a predominância do teste de paternidade através do DNA e, ainda, que este tem auxiliado significativamente como meio probatório nas varas cíveis do Sul de Minas Gerais.
\end{abstract}

Palavras- chave: Perícia Biológica. Análises Genéticas. Hereditariedade. Direito de Família.

\begin{abstract}
This paper presents the realization of paternity tests through the use of DNA, which began to be divulged in Brazilian media in the late twentieth century, through popular television programs and promoted their use in different social strata of Brazil. The research portrayed that the exam was already studied in the scientific milieu since the middle of the last century. The objective of this work was to investigate the types of DNA tests performed and if there is probative for the Court of Southern Minas Gerais. For this construct the research took an exploratory, descriptive profile, through a research script, investigating, describing and analyzing the data and approaches of the registry chiefs in $30 \%$ of the south of Minas Gerais civil varas. In the end, the research
\end{abstract}

\footnotetext{
1Doutora em Ciências com Área de Concentração em Biologia na Agricultura e no Ambiente pela USP e Prof. ${ }^{\text {a }}$ EBTT no IFSULDEMINAS. milena.biazuzo@muz.ifsuldeminas.edu.br.

2Mestre em Ciências Contábeis pela Fundação Escola de Comércio Alvarez Penteado - UNIFECAP, Prof. EBTT e Coord. no IFSULDEMINAS. erasmo.piccolo@muz.ifsuldeminas.edu.br.
}

3 Licenciada em Ciências Biológicas pelo IFSULDEMINAS. allynepongom48@gmail.com. 
found the predominance of the paternity test through DNA and, further, that it has helped significantly as a probative means in the civil courts of the South of Minas Gerais.

Keywords: Biological Expertise. Genetic Analyzes. Heredity. Family Right.

O teste de paternidade através do DNA começou a ser divulgado na mídia brasileira no final do século XX por meio de programas populares de televisão que promoveram o teste em diversas camadas sociais do Brasil. Contudo, o exame já era estudado no meio científico desde meados do século passado.

A invenção do teste deu-se em 1985 pelo inglês Alec Jeffreys por meio de uma técnica laboratorial de estudo simultâneo com "lanternas químicas" denominadas sondas multilocais que permitiam identificar padrões semelhantes, como em um código de barras, por exemplo. $\mathrm{O}$ exame ficou conhecido como "impressões digitais de DNA" em analogia as digitais dos polegares, as quais são únicas para cada indivíduo. A análise de DNA é realizada pela comparação de um conjunto de genes que formam diversas características e são localizados no cromossomos, permitindo a comparação do DNA de diferentes indivíduos através da separação das diferentes amostras de DNA em um campo elétrico (técnica de eletroforese) (PENA, 2010).

A popularização do teste de DNA resultou no aumento da demanda do exame. Em conformidade com Dourado (2008), no Brasil, as técnicas genéticas são consideradas formas para garantir o direito à informação e impulsionou o "mercado de paternidade", uma vez que a utilização do teste de DNA constitui uma forma probante por meio de métodos não sujeitos a falibilidade e impulsiona a sua utilização como meio de produção de prova no processo civil (BARROS; PISCINO, 2008). A utilização do exame de DNA no processo judicial brasileiro está ligada diretamente com a produção de prova no processo civil, especificamente em relação ao Direito de Família (BARROS; PISCINO, 2008).

Além disso, o teste de DNA não se limita apenas a casos judiciais, mas também a casos sociais, o que se comprova pela importância destes exames para a população brasileira, uma vez que no Brasil, são feitos 50 mil testes de DNA por ano, número que inclui exames realizados por órgãos públicos como o Imesc (MELLO, 2010). 
Nesse contexto, com o aumento da utilização do teste de DNA como ferramenta probatória no judiciário, o objetivo do trabalho foi investigar os tipos de testes de DNA e sua eficácia probatória nas varas cíveis do sul de Minas Gerais.

\section{Referencial teórico}

\subsection{Conceito de perícia}

Peritos são todos os profissionais de nível superior, concursados ou não, mas especializados em determinada área de conhecimento humano e que, por designação da autoridade competente (delegado de polícia ou autoridade judiciária), prestam serviços à justiça ou polícia a respeito de fatos, pessoas ou coisas (DEL-CAMPO, 2009).

A perícia é uma das provas, que possui condições de transmitir no processo judicial, autenticidade aos fatos que necessitam habilidade técnica ou científica especial (PICCOLO apud. SANTIN e BLEIL,2012). O bom trabalho pericial apresenta: objetividade, precisão, clareza, fidelidade, concisão, confiabilidade inequívoca baseada em materialidades e plena satisfação da finalidade (PICCOLO apud. SÁ, 2012).

\subsection{Perícia biológica}

A perícia biológica pode ser realizada na maior parte dos crimes em que sejam deixados vestígios biológicos (sangue, cabelos, digitais, etc.) podendo, inclusive, auxiliar na solução desses crimes. Por abranger várias áreas, tais como: busca de drogas, investigação criminal, teste de paternidade; a perícia biológica vem sendo de grande importância na justiça. Como parte da perícia biológica encontram-se a genética e a biologia forense, as quais têm auxiliado a justiça a desvendar crimes (RUI, 2016).

\section{3 Ácido Desoxirribonucleico (DNA)}


O ácido desoxirribonucleico (DNA) é um componente celular crucial para a manutenção da vida de todos os seres vivos, sendo responsável, juntamente com o ambiente, pela determinação de todas as características morfológicas e fisiológicas de um indivíduo.

O DNA é composto por fosfato, açúcar (desoxirribose) e bases nitrogenadas (adenina, timina, guanina e citosina) que formam a dupla hélice do DNA (Figura 1). Essa molécula é capaz de replicar-se a fim de transmitir a informação genética para as células em divisão celular, tanto para a formação de células somáticas de um indivíduo, quanto para a formação de gametas, os quais carregarão a informação genética dos pais para a formação do novo indivíduo (filho).

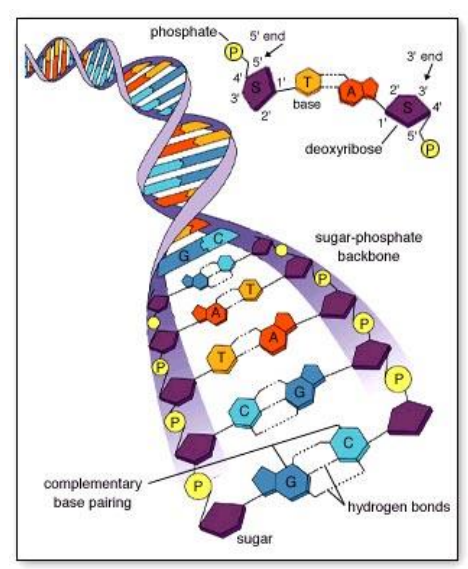

Figura 1. Constituição molecular do DNA (MARCEL, 2016).

O DNA contém informações genéticas que orientam a atividade celular, gerando o desenvolvimento, a atividade e o comportamento de organismos, podendo, em algumas situações, modificar-se para a adaptação às diferenças e circunstâncias ambientais (SNUSTAD; SIMONS,2013).

O DNA presente nos cromossomos pode apresentar-se sob duas formas: a compactada e a descompactada (Figura 2). 


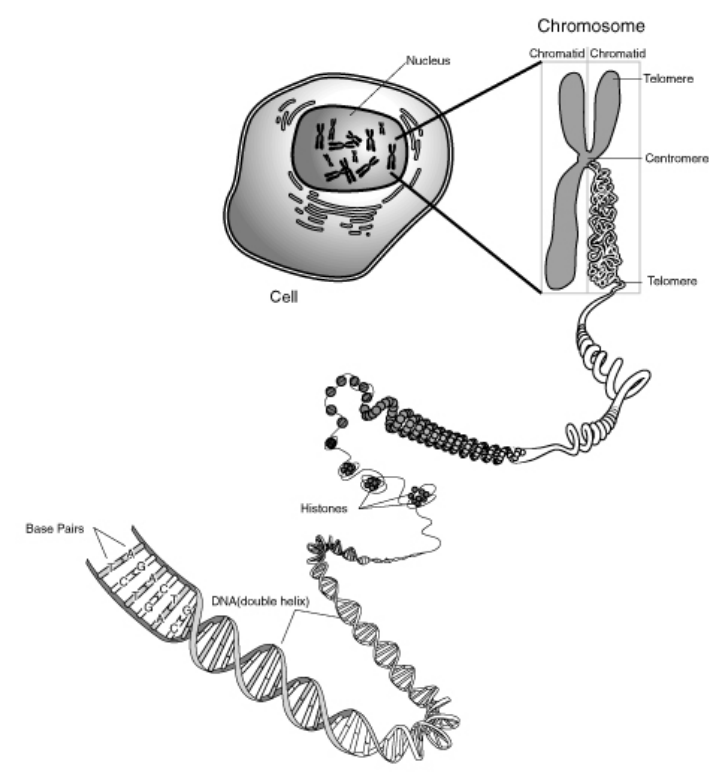

Figura 2. Cromossomo condensado e descondensado (MARCEL, 2016).

Através do DNA é possível determinar as características de um indivíduo a partir dos alelos, os quais são formas alternativas de um mesmo gene e afetam a mesma característica de modo diferente. Há os alelos recessivos e os alelos dominantes, sendo os mesmos diferenciados por letras minúsculas e maiúsculas, respectivamente. Os alelos encontram-se cada um em um cromossomo, sendo um alelo proveniente do gameta feminino e outro do masculino (GONÇALVES; FORTUNA, 2016) (Figura 3).

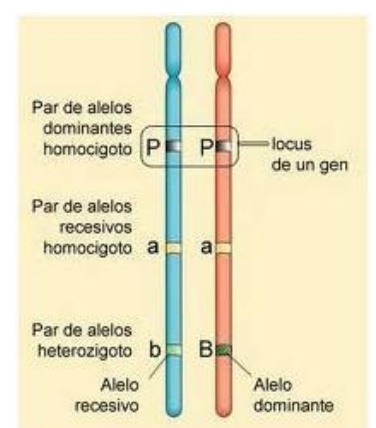

Figura 3. Cromátides do cromossomo com seus diferentes alelos (FORTUNA, 2016)

Na década de 90 do século XX, tiveram início no Brasil, os primeiros testes de paternidade, utilizando a técnica da PCR (sigla em inglês para 'reação em cadeia da polimerase'), em substituição às perícias de paternidade feitas com sondas. A principal vantagem da técnica de PCR é o emprego de menor quantidade de DNA. Por isso, 
embora não tão informativos e elegantes quanto as "impressões digitais de DNA", vieram mais tarde a substituí-las nos laboratórios (PENA, 2010).

As interpretações dos resultados dependem do poder de discriminação das técnicas, o qual varia de acordo com características de cada grupo populacional. Qualquer falha entre a coleta de amostras e a divulgação dos resultados pode levar a conclusões equivocadas em exames de DNA (PARADELA; FIGUEIREDO, 2007).

Existem 21 tipos de exames de DNA, sendo eles: (i) biópsia cervical; (ii) biópsia oral; (iii) biópsia peniana; (iv) biópsia de pele; (v) biópsia parafina; (vi) biópsia de próstata; (vii) líquido amniótico; (viii) escarro (lavado brônquico alveolar e líquido pleural); (ix) líquido céfalo raquidiano; (x) Osso; (xi) pcap-sangue total (tubo EDTA); (xii) plasma; (xiii) raiz de cabelo; (xiv) raspado peniano (glande/prepúcio, suco bálamo e outros); (xv) sangue fetal (tubo EDTA); (xvi) sangue total (tubo EDTA e papel FTA); (xvii) sêmen pré e pós-tratamento; (xviii) soro; (xix) swab bucal (saliva e genitais); (xx) Unha; (xxi) urina e vilo coriônico.

Estes exames de DNA vão variar quanto à forma de coleta, ao local de coleta e como deve ser armazenado e transportado, sendo esses fatores de extrema importância para conservação do material pra a realização do teste (BIOGENETICS, 2016).

\subsection{Teste de paternidade}

Para que haja a identificação de uma pessoa através de seu DNA são utilizadas sondas capazes de detectar sequências do DNA humano. Essas sequências de DNA são chamadas de VNTR (Variable Number of Tandem Repeats - número variável de repetições em sequência) e são compostas por sequências curtas de nucleotídeos que se repetem ao longo de trechos da molécula de DNA. Cada pessoa tem um padrão específico de repetição dessas unidades e esse padrão é herdado de seus pais (MORAES, 2015) (Figura 4). 


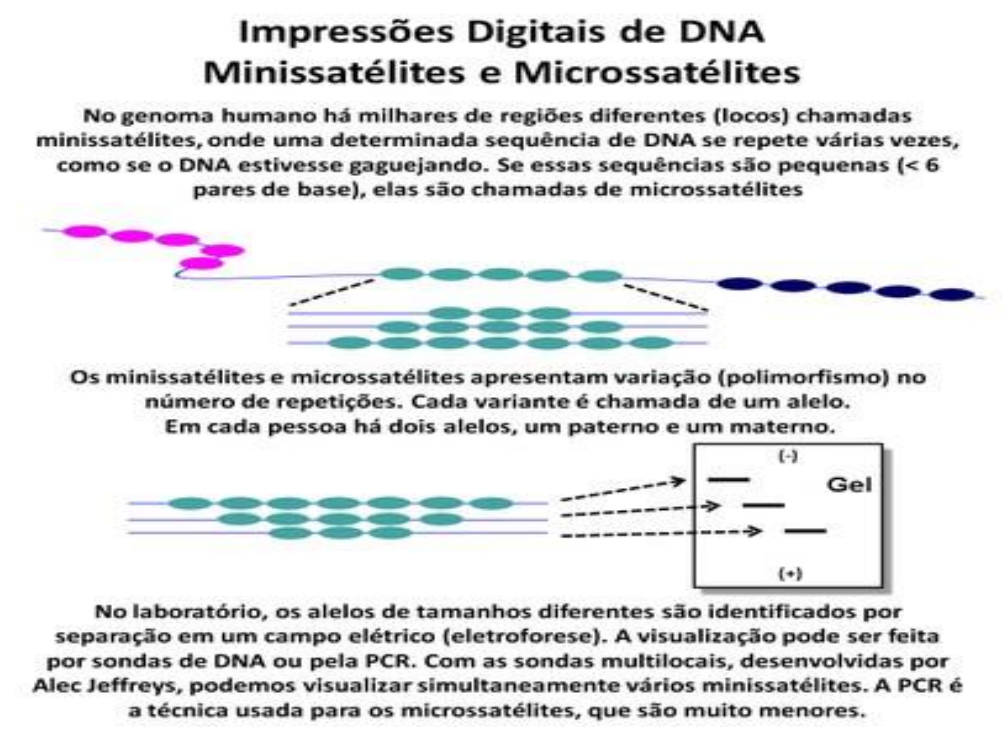

Figura 4. Impressões digitais de DNA: Minissatélites e Microssatélites (PENA, 2016).

Genoma é o conjunto de genes que compõem um organismo. No genoma há regiões diferentes chamadas de minissatélites, nas quais uma determinada sequência de DNA repete-se por várias vezes, sendo que se essa sequência de repetições forem pequenas são chamadas de microssatélites (Figura 4). Os minissatélites e microssatélites apresentam variação quanto ao número de repetições; cada variante é chamada de alelo, cada pessoa possui dois alelos (paterno e materno) e estes alelos determinam as características do indivíduo. Os alelos que possuem tamanhos diferentes, são separados e identificados em um campo elétrico, através da técnica de eletroforese, sendo sua visualização realizada por sondas de DNA ou PCR.

\subsection{Tecnologias e equipamentos}

Na década de 1990, o exame de DNA revelou-se uma das principais ferramentas da ciência forense para a identificação de suspeitos. Naquela época, o tempo que levava para especialistas chegarem a um relatório eram de oito semanas. Hoje em laboratório, é possível realizar todo o processo em menos de uma hora, tornando-se viável a realização do exame com pequenas amostras de DNA, podendo esta estar em pior conservação (TOLEDO, 2013).

O projeto Genoma Humano teve início em 1990 com o objetivo de identificar a sequência de bases de cada gene do organismo humano. Através do Fingerprinting, 
projeto onde as regiões formadas por unidades que possuem sequências definidas de bases são mapeadas, tornou-se possível identificar pessoas e fazer testes de paternidade, sendo útil também para identificar suspeitos de um crime (GONÇALVES, 2016).

A técnica de PCR (sigla em inglês para 'reação em cadeia da polimerase'), laureou em 1993 com prêmio Nobel de Química os seus inventores: Kary Mullis e Michael Smith. Essa técnica de biologia molecular torna possível a obtenção de muitas cópias de uma sequência específica de DNA, tornando-se vital em diversas aplicações genômicas, que vão desde pesquisas de clonagem até testes de investigação de paternidade.

A PCR é definida como uma técnica de amplificação de DNA sem utilizar organismos vivos. Ela é utilizado pelos laboratórios de investigação médica e biológica, objetivando diferentes tarefas, sendo uma delas o teste de paternidade e para a realização deste procedimento, primeiramente é necessário extrair o material genético da célula ou do local a ser estudado com cautela para que não haja danificação e contaminação. Atualmente, o material coletado é o DNA. Sendo feita a coleta, é adicionada uma mistura, também chamada de pré-mix, com dNTPs (desoxirribonucleotídeos trifosfato), primers (bases ligadas a três fosfatos também chamados oligonucleotídeos ou iniciadores) e a enzima DNA polimerase em uma solução tampão. Este material é colocado em um equipamento conhecido como termociclador, no qual o material é aquecido a uma temperatura entre $90^{\circ}$ a $96^{\circ} \mathrm{C}$ para que ocorra a desnaturação do DNA (separação das fitas), em seguida, há uma queda de temperatura para $50^{\circ}$ a $60^{\circ} \mathrm{C}$ ocorrendo a hibridização ou anelamento com os primers. Neste ponto, os primers ligam-se com especificidade às suas sequências complementares do DNA. Após isso, aumenta-se a temperatura para $72^{\circ} \mathrm{C}$ novamente para que ocorra a síntese pela polimerase (extensão de uma nova molécula de DNA). Este ciclo de resfriamento e aquecimento devem ser realizados de 25 a 40 vezes (Figura 5). 


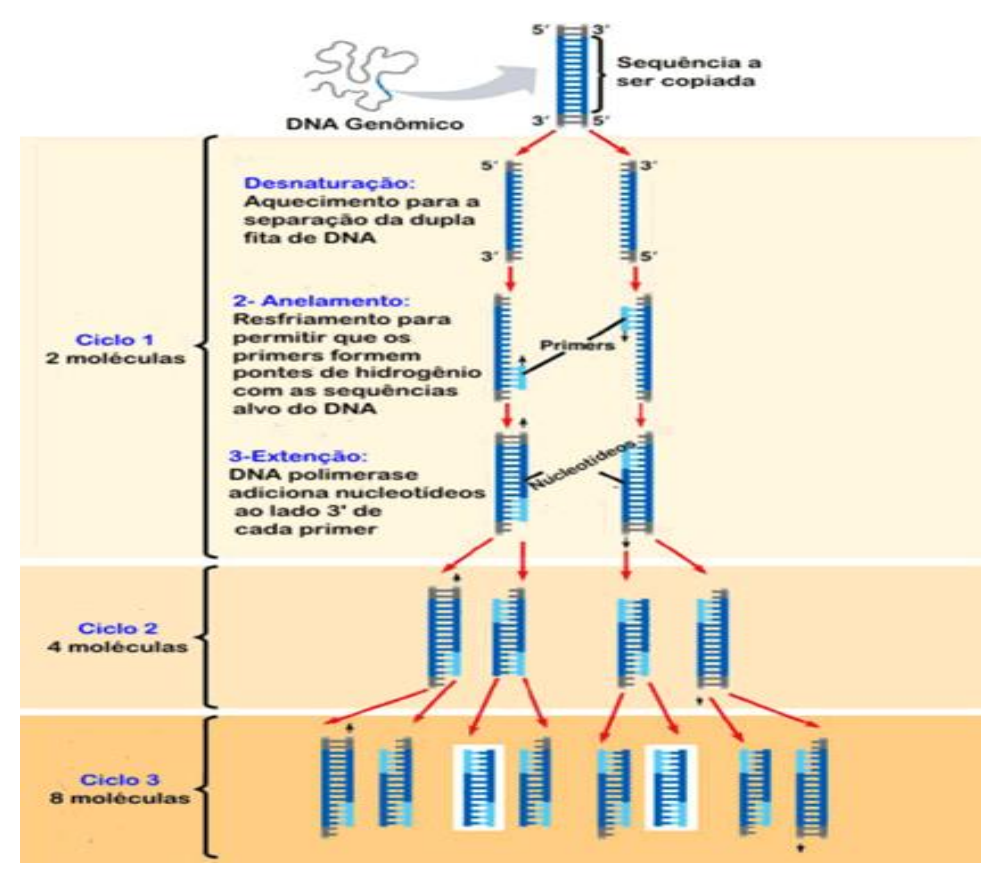

Figura 5. Reação em Cadeia da Polimerase (PCR) (FREIRE, 2016).

Após a realização da PCR, as diferentes amostras de DNA amplificado são aplicadas no gel de agarose ou poliacrilamida, sendo aplicada corrente elétrica para a movimentação do DNA no gel (Figura 6), formando as bandas, as quais devem apresentar semelhança com as dos pais, sendo que as que forem semelhantes, terão parentesco e as que não forem, indicam que não há parentesco algum. As bandas são, na verdade, os alelos responsáveis pelas caraterísticas do indivíduo, os quais são herdados dos pais.

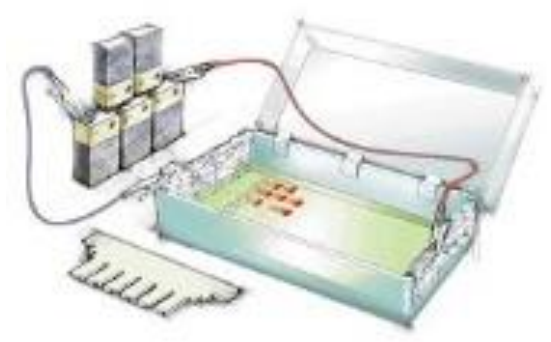

Figura 6. Eletroforese para separação de amostras de DNA (NICÉSIO, 2016).

No resultado de eletroforese apresentado na Figura 7, observa-se que apenas os indivíduos I e III são filhos do referido pai, pois ambos têm todas as bandas (alelos) coincidentes com a mãe ou o pai. 


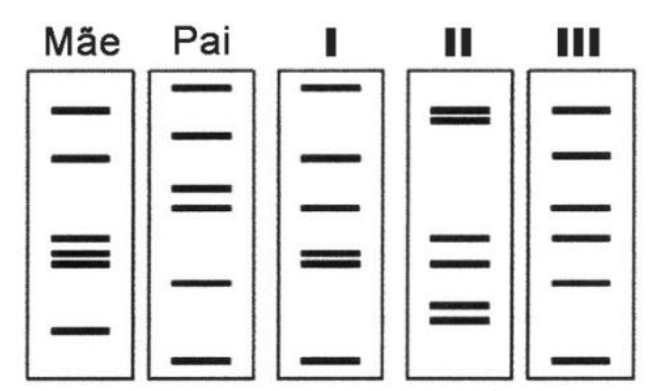

Figura 7. Resultado de Eletroforese (SANTOS, 2016).

\subsection{Sul de Minas Gerais}

O Sul de Minas Gerais teve uma forte expansão populacional, incentivada pelo deslocamento rural dos escravos libertos, pela melhoria das condições de vida nas cidades e pela intensificação da imigração europeia. A Região do Sul de Minas, em comparação com a população do Estado, apresenta uma estrutura etária envelhecida. Com 155 cidades, o Sul de Minas Gerais, no ano de 2010, possuía aproximadamente 2,5 milhões de habitantes e as microrregiões de Passos, Poços de Caldas, Varginha e Pouso Alegre são as mais populosas (GOVERNO DE MINAS, 2014).

O trabalho trata da contribuição da perícia biológica no Tribunal de Justiça do Sul de Minas Gerais, sendo estudadas as regiões destacadas na Figura 8.

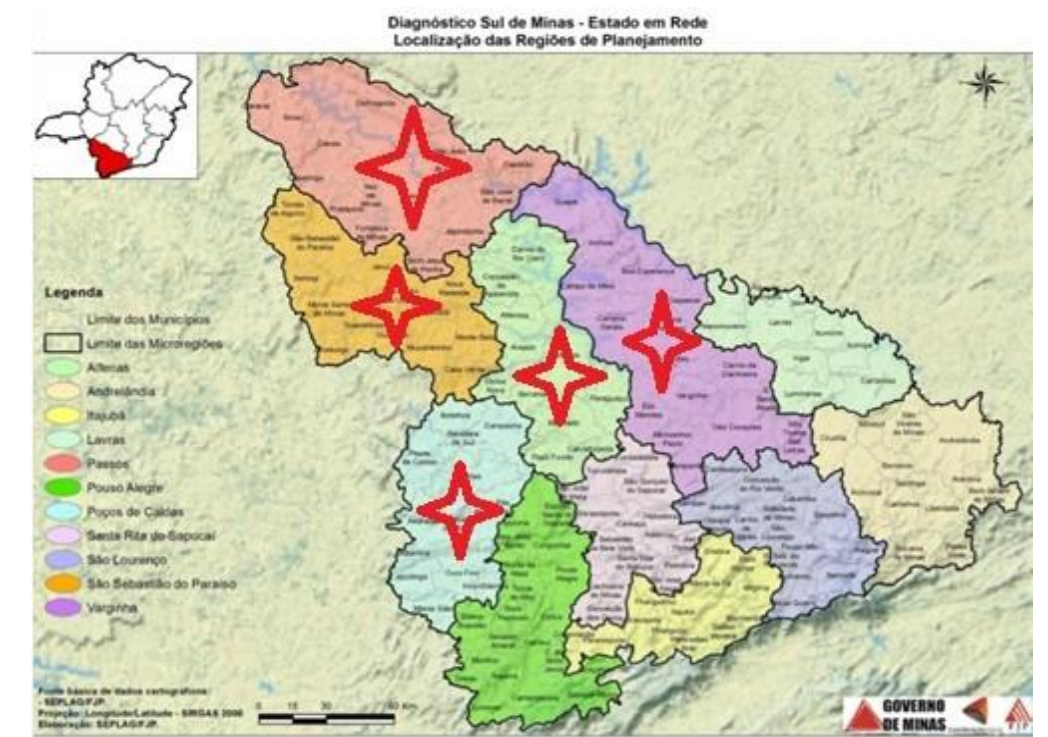

Figura 8. Sul de Minas Gerais (Caderno Regional Sul de Minas). 


\subsection{Tribunal de justiça}

O Tribunal de Justiça de Minas Gerais (TJMG) tem como missão "garantir, no âmbito de sua competência, a prestação jurisdicional com qualidade, eficiência e presteza, de forma a atender aos anseios da sociedade e constituir-se em instrumento efetivo de justiça, equidade e de promoção da paz social” (TJMG, 2016).

No estado de MG há seis varas judiciais. Para que haja a especialização do juiz titular de uma vara em um assunto determinado e para maior agilidade na resolução dos processos de mesma tipificação, as varas são divididas em várias especialidades, tais como: vara da família; vara de fazendas públicas e autarquias; vara da infância e da juventude; vara de meio ambiente, habitação e urbanismo; vara do idoso e vara Maria da Penha (TJMG, 2016).

\section{Metodologia da pesquisa}

A pesquisa é do tipo descritiva e exploratória com etapas pré-estabelecidas. Inicialmente com o estudo da literatura da área e em seguida, com o perfil de estudo de caso conforme Cervo, Bervian e Silva (2007).

O trabalho objetivou a verificação da utilização da perícia biológica no Sul de Minas Gerais. Para isso, foram aplicados roteiros de entrevista em 36 fóruns da região do Sul de Minas Gerais. Inicialmente, foram visitadas as varas cíveis próximas da cidade de Muzambinho - MG e, em seguida, foram enviados e-mails para todos os fóruns presentes no sul de Minas Gerais, contendo o roteiro de entrevista para serem respondidos e retornados na forma digitalizada.

Após a obtenção dos roteiros respondidos e mapeados, foram elaborados gráficos para ilustrar as abordagens encontradas e, por fim, analisados os conteúdos, o que permitiu confrontar e identificar as assertivas investigadas, bem como concluir o problema de pesquisa. 


\section{Resultados e discussão}

As varas cíveis pesquisadas afirmaram haver pelo menos a realização de um tipo de perícia biológica na cidade, sendo constatados 98 testes de paternidade através de exames de DNA, na somatória das respostas do roteiro de entrevista. De acordo com os investigados, o teste de DNA não vem sendo muito solicitado. $\mathrm{Na}$ cidade de Botelhos, é realizado o Projeto Pai Presente, no qual o fórum juntamente com as escolas da cidade tentam encontrar o pai de crianças que ao serem matriculadas, estão com a falta do pai em sua vida, sendo este projeto realizado também com os jovens e adultos que não sabem a localização de seu pai.

A contribuição da perícia biológica, enfatizando o teste de DNA, é evidente, visto que $100 \%$ dos chefes de cartório afirmaram que ela tem contribuído como meio probatório na vara civil em que atuam. Afirmaram, inclusive, que esta é a única prova utilizada, sendo uma prova contundente no caso de paternidade, resultado esse que contradiz Dourado (2008).

Durante a realização da pesquisa, o pressuposto era de que o número de pessoas que teriam preferência por pagar pelo teste de paternidade (DNA) seria maior do que as que teriam preferência por fazê-lo de forma gratuita, devido principalmente à maior agilidade e ao baixo custo (valor de referência atual: $\mathrm{R} \$ 300,00$ ) (MELLO, 2016). Entretanto, conforme é apresentado na Figura 9, 67\% dos sul-mineiros preferem fazer o teste de paternidade de forma gratuita e apenas 33\% preferem pagar por tal perícia. Ao questionar-se o porquê para os responsáveis de cada vara cível, declarou-se que os testes pagos são preferidos por aqueles que possuem condições financeiras para pagar, devido à maior agilidade, sendo que em alguns casos as pessoas já levam os resultados somente para a análise do juiz. Já, no caso dos testes gratuitos, essa escolha deve-se, na maior parte das vezes, às condições financeiras das famílias envolvidas. 


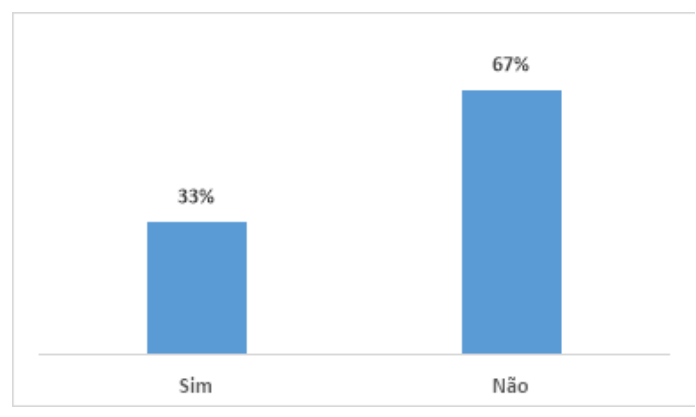

Figura 9. Preferência em pagar pela perícia biológica.

Outro ponto avaliado foi o tempo para a realização do teste de paternidade. No caso do teste de DNA pago, 100\% das varas cíveis interrogadas, afirmam que leva em torno de 30 dias para ficar pronto. Quanto ao teste gratuito, $44 \%$ dos entrevistados assinalaram que o teste leva cerca de 4-6 meses para ficar pronto, enquanto outros $53 \%$ afirmam que o teste de DNA, por não estar sendo muito procurado, leva menos de 3 meses para ficar pronto (Figura 10). Sendo assim, a pesquisa revela que o teste de paternidade (DNA) gratuito também pode ser feito de forma ágil, solucionando os casos rapidamente.

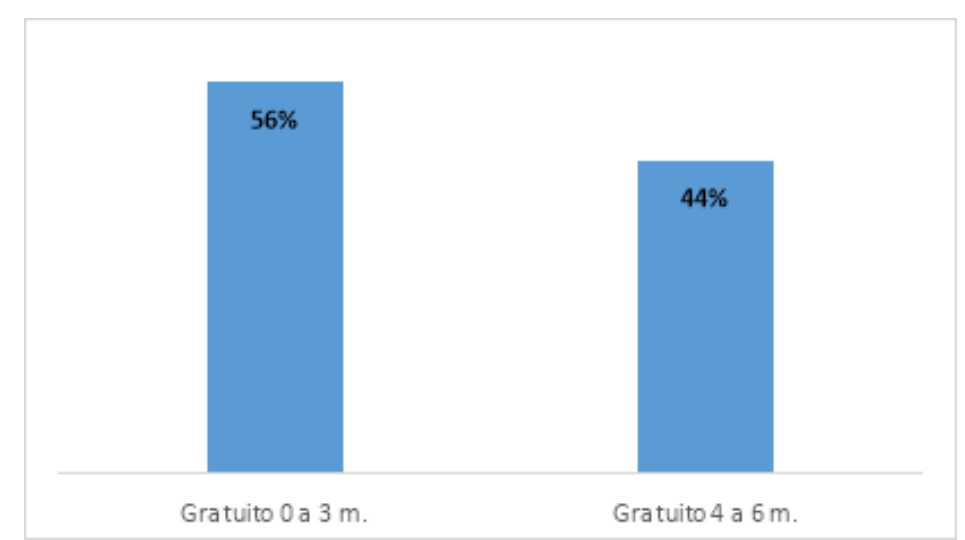

Figura 10. Tempo para realização do teste de DNA gratuito.

Quando questionados sobre a presença de um funcionário judicial para realização do teste de DNA, 78\% dos entrevistados afirmaram que não há presença deste na realização do teste, pelo fato do mesmo ser realizado em laboratórios credenciados com o TJMG, sendo responsáveis por toda a coleta de material (sanguíneo ou oral). Já os outros $22 \%$ afirmaram que há funcionários do TJMG participando de todo o processo de coleta (no caso do teste gratuito), com os materiais 
que os laboratórios disponibilizam para coleta, sendo a amostra biológica coletada mais frequentemente, neste caso, a saliva (Figura 11).

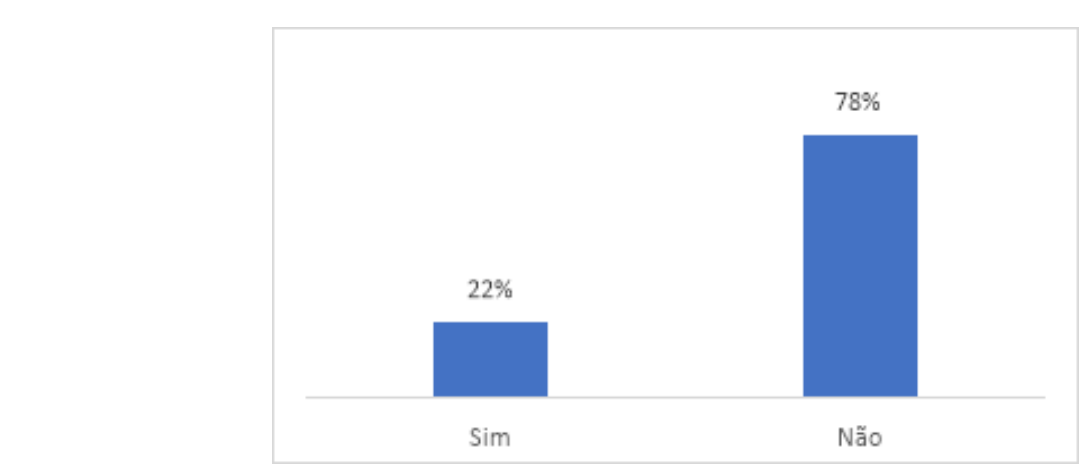

Figura 11. Acompanhamento de funcionário do TJMG na realização do teste de DNA.

Questionou-se também sobre as possíveis fraudes que poderiam ocorrer durante a realização da coleta do material a ser analisado, e quais penas o indivíduo teria de cumprir caso houvesse tal troca de amostra. Todas as varas afirmaram não ter havido até a data presente, nenhuma fraude e algumas disseram que caso tal fraude ocorresse, os indivíduos teriam de responder cível e criminalmente, não tipificando o crime que teriam de responder.

Cabe ressaltar que, caso tal fraude ocorresse, os acusados enquadrariam-se ao processo de obstrução à justiça, podendo cumprir pena de 6 meses à 2 anos de reclusão inafiançável.

\section{Considerações finais}

A pesquisa concluiu que a perícia biológica é utilizada como meio probatório e assim assume papel significativo no Tribunal de Justiça do Sul de Minas Gerais, ou seja, 100\% dos entrevistados confirmaram a utilização do teste como meio probatório e ainda que o teste de DNA para paternidade seja o único meio probatório no deslindar e conclusão destes tipos de litígios. Contudo, a realidade encontrada em termos de quantidade de testes nas varas cíveis ainda está muito aquém do necessário, visto que foram realizados somente 98 testes nas comarcas pesquisadas, no período de um ano.

Embora o teste de DNA gratuito seja mais demorado para ser realizado em comparação com o teste pago, a pesquisa constatou que $67 \%$ das pessoas aderem aos 
testes gratuitos, segundo os pesquisados isto ocorre devido à realidade econômica e financeira das pessoas que realizam o teste de DNA.

Constatou-se também que na grande maioria (78\%), não há o acompanhamento de um funcionário judicial para o levantamento da amostra e na realização do teste de DNA. Contudo os pesquisados foram unânimes em afirmar que nunca tiveram problemas de fraudes nas coletas e nos exames, pois se tratavam de órgãos credenciados pela justiça, e caso esse tipo de situação ocorresse, os envolvidos responderiam civil e criminalmente.

Embora este tema seja de relevância social, constatou-se poucas pesquisas sobre o assunto, desta forma recomenda-se aos que se interessarem em ampliar esta pesquisa, podendo reaplicá-la em outras regiões.

\section{Referências}

BARROS, Marco Antonio. Piscino, Marcos Rafael Pereira. DNA e sua utilização como prova no processo penal. Universidade Presbiteriana Mackenzie. 2008. disponível em: <http://www.esmal.tjal.jus.br/arquivosCursos/2015_05_11_14_08_46_Artigo.DNA.Prov a.Marco.Antonio.Barros.pdf $>$. Acesso em: 10 de dezembro de 2015.

BIOGENETICS. Coleta e Armazenamento. Disponível em:

$<$ http://www.biogenetics.com.br/>. Acesso em: 25 de julho de 2016.

BRASIL. Governo Estadual de Minas Gerais. Caderno Regional do Sul de Minas Gerais. Minas Gerais, 2014.

BRASIL. Tribunal de Justiça do Estado de Minas Gerais-TJMG. Minas Gerais: Belo Horizonte,2016.

CERVO, A. L.; BERVIAN, P. A.; SILVA, R. (2007). Metodologia científica (6th ed.). São Paulo: Pearson.

DEL-CAMPO, Eduardo Roberto Alcântra. Exame e levantamento técnico pericial de locais de interesse a justiça criminal: abordagem descritiva e critica. Tese MestradoFaculdade de Direito da Universidade de São Paulo-USP, São Paulo,2008. Disponível em: < http://www.teses.usp.br/teses/disponiveis/2/2136/tde-27052010-093136/ptbr.php>. Acesso em 30 de julho de 2016.

DOURADO, Flávia. Teste de DNA: democratização de informação e tecnologia? UNICAMP. 2008. Disponível em: $<$ http://www.labjor.unicamp.br/midiaciencia/article.php3?id_article=646 > . Acesso em: 10 de dezembro de 2015. 
FORTUNA, Gabriela Marfa. Gene, Alelo, Genótipo e Fenótipo. UFF. 2016. Disponível em: $<$ http://www.lgqma.uff.br/monitorias/Gabriela/alelo.html $>$. Acesso em: 31 de maio de 2016.

FREIRE, Alexandre de Sá. Diagnóstico Molecular. Alegria, Alegria no site da Biologia. Disponível em:< http://bioalegria.blogspot.com.br/2011/04/diagnostico-molecular.html $>$. Acesso em: 25 de julho de 2016.

GONÇALVES, Fabiana Santos. Termos usados em Genética. Infoescola. Disponível em: <http://www.infoescola.com/biologia/termos-usados-em-genetica/>. Acesso em: 31 maio de 2016.

MARCEL, Guellity. O que é DNA? Eu quero Biologia. Disponível em:<http://euquerobiologia.blogspot.com.br/2014/04/o-que-e-dna.html $>$. Acesso em: 25 de julho de 2016.

MELDAU, Débora Carvalho. Reação em Cadeia da Polimerase. Infoescola. Disponível em: $<$ http://www.infoescola.com/genetica/reacao-em-cadeia-da-polimerase/ > . Acesso em: 27 de junho de 2016.

MELLO, Kátia. De cada dez homens que pedem exame de DNA, três descobrem que não são pais de seus filhos; Época. Disponível em:

<http://revistaepoca.globo.com/Revista/Epoca/0,EMI187549-15228,00-

DE+CADA+DEZ+HOMENS+QUE+PEDEM+EXAME+DE+DNA+TRES+DESCOBRE

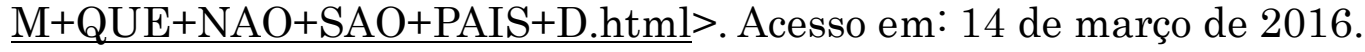

MONIZ, Priscilla. DNA- tecnologias relacionada. Educação.globo. Disponível em: $<$ http://educacao.globo.com/biologia/assunto/genetica/dna-tecnologiasrelacionadas.html>. Acesso em: 01 de junho de 2016.

MORAES, Paula Louredo. "Teste de DNA"; Brasil Escola. Disponível em: $<$ http://brasilescola.uol.com.br/biologia/teste-de-dna.htm $>$. Acesso em 09 de dezembro de 2015.

NICÉSIO, Raphael Gonçalves. Eletroforese Biomedicina Brasil. Disponível em: $<$ http://www.biomedicinabrasil.com/2010/10/eletroforese.html $>$. Acesso em: 25 de julho de 2016.

PARADELA, Eduardo Ribeiro; FIGUEIREDO, André Luís dos Santos. O DNA vai ao tribunal: o impacto das tipagens genéticas. [2007]. Disponível em:

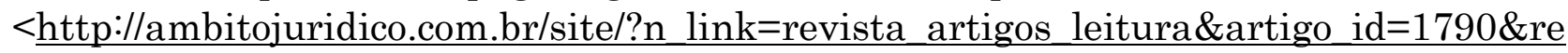
vista_caderno=14>. Acesso em: 25 jul. de 2016.

PENA, Sérgio Danilo. A revolução dos testes de DNA. Instituto CH - Ciência Hoje. Disponível em:

<http://www.cienciahoje.org.br/noticia/v/ler/id/4321/n/a_revolucao_dos_testes_de_dna $>$ . Acesso em: 25 de junho de 2016. 
PICCOLO, Erasmo Aparecido. PROCEDIMENTOS PERICIAIS EM PROCESSOS CÍVEIS DE OPERAÇÕES DE CHEQUE ESPECIAL NA REGIÃO DE BAURU-SP.91f. Tese Mestrado-Fundação Escola de Comércio Álvares Penteado-FECAP, São Paulo,2012. Disponível em: < http://tede.fecap.br:8080/jspui/handle/tede/506\#previewlink0> Acesso em: 25 de junho de 2016.

QUINETE, Rowilson. Os genes não mentem. Super Interessante. Disponível em: $<$ http://super.abril.com.br/ciencia/os-genes-nao-mentem-jamais $>$. Acesso em: 25 de junho de 2016.

REDAÇÃO O Futuro das Coisas. Nova tecnologia com luzes LED torna os testes de DNA mais rápidos, baratos e portáteis, O futuro das Coisas. Disponível em: $<$ http://ofuturodascoisas.com/nova-tecnologia-que-usa-ouro-e-led-torna-os-testes-dedna-mais-rapidos-baratos-e-portateis/>. Acesso em: 21 jun. de 2016.

RUI, Fernando. Pericia Criminal-Biologia Forense. Ebah. Disponível em: $<$ http://www.ebah.com.br/content/ABAAAALIkAE/pericia-criminal-biologiaforense?part=3>. Acesso em: 10 de janeiro de 2016.

Recebido em março de 2018. Aprovado em novembro de 2018. 